\title{
Pemanfaatan E-Modul Berbasis Smartphone Sebagai Media Literasi Masyakarat
}

\author{
Gufran $^{1}$, Imran Mataya ${ }^{2}$
}

\begin{abstract}
Abstrak: Pengembangan dan penguatan gerakan literasi menjadi salah satu unsur yang penting dalam sebuah negara dalam menjalani kehidupan di era globalisasi. Forum Ekonomi Dunia 2015 telah memberikan gambaran tentang keterampilan abad ke-21 yang sebaiknya dimiliki oleh seluruh bangsa di dunia yaitu meliputi keterampilan literasi dasar, kompotensi dan karakter. Data dari PISA 2015 yang diumumkan pada awal Desember 2016 menunjukkan bahwa literasi sain dan matematika anak-anak Indonesia berada di urutan 64 dari 72 negara. Kemudian hasil skor Asesmen kompotensi siswa indonesia (AKSI) yang mengukur kemampuan membaca, matematika, dan sains bagi anak sekolah dasar juga menunjukkan hasil yang memprihatinkan. Secara Nasional yang masuk kategori kurang untuk kemampuan matematika sebanyak 77,13\% kemampuan membaca 46,83\% dan kemampuan sains $73,61 \%$. Minat baca dan literasi bangsa indonesia merupakan persoalan yang harus ditangani secara serius. Minat baca dan literasi bangsa harus menyamai dan bahkan lebih tinggi daripada bangsa lain yang sudah maju agar bangsa Indonesia juga berperan dalam percaturan global. Literasi tidak hanya di pahami sebagai kemampuan membaca dan menulis tetapi juga dipahami sebagai kemampuan memanfaatkan hasil bacaan menyelenggarakan berbagai kegiatan literasi untuk meningkatkan indeks literasi Nasional melalui Gerakan Literasi Nasional (GLN). Realitas kehidupan masyarakat saat ini tidak lepas dari gadget disisi lain literasi membaca dan menulis masih rendah maka diperlukan langkah strategis untuk mendukung gerakan literasi nasional yaitu bagaimana menyiapkan media literasi yang mampu membangkitkan semangat literasi masyarakat salah satunya dengan pemanfaatan E-Modul berbasis smartphone. E-Modul merupakan media pengajaran digital dan non cetak yang disusun secara sistematis dan digunakan untuk keperluan belajar mandiri, guna menuntut masyarakat untuk belajar memecahkan masalah dengan caranya sendiri. E-modul dapat di akses dengan menggunakan aplikasi e-Pub yang dipasang pada smartphone sehingga dapat di akses kapan saja dan dimana saja E-modul sebagai media literasi masyarakat diharapkan mampu mengalihkan perhatian masyarakat yang awalnya memanfaatkan smartphone hanya untuk sosial media tetapi dengan materi yang dikemas menarik dalam bentuk buku elektronik yang dilengkapi dengan video dan audio diharapkan dapat meningkatkan literasi masyarakat
\end{abstract}

Kata Kunci: e-modul, Smartphone, Media Literasi

\section{PENDAHULUAN}

Pengembangan dan penguatan gerakan literasi menjadi salah satu unsur yang penting dalam sebuah negara dalam menjalani kehidupan di era globalisasi. Forum Ekonomi Dunia 2015 telah memberikan gambaran tentang keterampilan abad ke-21 yang sebaiknya dimiliki oleh seluruh bangsa di dunia yaitu meliputi keterampilan literasi dasar, kompotensi dan karakter. Untuk menyukseskan pembangunan Indonesia di abad 21 menjadi keharusan bagi masyarakat indonesia untuk menguasai enam literasi dasar yaitu (1) literasi bahasa, (2) literasi numerasi, (3) literasi sains, (4) literasi digital, (5) literasi finansial, serta (6) literasi budaya dan kewarganegaraan. Kemampuan literasi harus di imbangi dengan menumbuhkembangkan kompetensi yang meliputi kemampuan berpikir kritis, kreativitas, komunikasi dan kolaborasi.

Untuk meningkatkan kualitas hidup, daya saing, pengembangan karakter bangsa, serta melihat perkembangan keterampilan dan kompetensi yang dibutuhkan di abad ke-21, pemerintah melalui Kementerian Pendidikan dan Kebudayaan sedang berusaha meningkatkan literasi bagi masyarakat khususnya siswa. Data dari PISA 2015 yang diumumkan pada awal Desember 2016 menunjukkan bahwa literasi sain dan matematika anak-anak Indonesia berada di 
urutan 64 dari 72 negara. Kemudian hasil skor Asesmen kompotensi siswa indonesia (AKSI) yang mengukur kemampuan membaca, matematika, dan sains bagi anak sekolah dasar juga menunjukkan hasil yang memprihatinkan. Secara Nasional yang masuk kategori kurang untuk kemampuan matematika sebanyak $77,13 \%$ kemampuan membaca $46,83 \%$ dan kemampuan sains $73,61 \%$. Berdasarkan data di atas mengisyaratkan bahwa minat baca dan literasi bangsa indonesia merupakan persoalan yang harus ditangani secara serius. Minat baca dan literasi bangsa harus menyamai dan bahkan lebih tinggi daripada bangsa lain yang sudah maju agar bangsa Indonesia juga berperan dalam percaturan global. Literasi tidak hanya di pahami sebagai kemampuan membaca dan menulis tetapi juga dipahami sebagai kemampuan memanfaatkan hasil bacaan menyelenggarakan berbagai kegiatan literasi untuk meningkatkan indeks literasi Nasional melalui Gerakan Literasi Nasional (GLN).

GLN merupakan upaya untuk menyinergikan semua potensi serta memperluas keterlibatan publik dalam pengembangan budaya literasi. Pengembangan budaya literasi dapat dilakukan dengan pembudayaan literasi yang merata dan menyenangkan melalui pendidikan yang menyenangkan, berkesinambungan dan lingkungan yang menerapkan nilai-nilai baik dalam seluruh sendi kehidupan berbangsa dan bernegara. Oleh karena itu dunia pendidikan harus mampu menciptakan lingkungan belajar yang sehat, baik di sekolah maupun di masyarakat melalui pengembangan tempat belajar, jumlah dan potensi siswa, peningkatan kualitas guru, tenaga kependidikan, dan revitalisasi seluruh satuan pendidikan yang tersebar di seluruh indonesia. Untuk mencapai itu, penguatan sinergi antara pemerintah, orang tua, dan masyarakat tidak dapat di tawar-tawar lagi. Keterbatasan sarana belajar dan infrastruktur serta globalisasi menjadi tantangan yang jika tidak dikelola dengan baik dan cermat dapat melunturkan nilai-nilai luhur dan kearifan lokal bangsa Indonesia (Mendikbud, 2017).

Era revolusi digital memberikan kemudahan dan kenyamanan bagi kehidupan manusia sehingga mampu mengubah sendisendi kehidupan, kebudayaan, dan kemasyarakatan. Hal ini ditandai dengan fenomena abad 21 yang menempatkan informasi, pengetahuan, kreativitas, inovasi dan jejaring sebagai sumber daya strategis yang tidak hanya berpotensi positif, tetapi juga negatif. Asosiasi penyelenggara jasa internet Indonesia tahun 2016 merilis data $65 \%$ dari 132,7 juta pengguna internet berada di pulau jawa dan $69,8 \%$ pengguna internet adalah pelajar yang juga berpotensi mengakses isi dan fitur-fitur negatif. Data yang diperoleh menunjukkan bahwa $40 \%$ pengguna internet mengakses internet lebih dari 3 jam perhari. Data Komeninfo tahun 2017 menunjukkan bahwa 60 juta penduduk indonesia memiliki gadget, urutan kelima dunia terbanyak kepemilikan gadget. Pada tahun 2018 sekitar 100 juta orang jumlah pengguna smartphone yang aktif, dengan jumlah sebanyak itu indonesia akan menjadi negara dengan pengguna aktif smartphone tersebar keempat di dunia setelah cina, india dan amerika. Ironisnya meski minat baca buku rendah tapi data wearesosial per Januari 2017 mengungkapkan orang indonesia bisa menatap layar gadget kurang lebih 9 jam sehari. Oleh karena itu perlu digali strategi pengembangan kompetensi literasi yang mempertimbangkan pergeseran media informasi dari cetak/luring (offline) ke digital/daring (online). Kompetensi literasi digital dan media ini sejalan dengan kurikulum 2013 yang menekankan kepada integrasi berbagai jenis media dalam pembelajaran yang berpusat kepada peserta didik. Oleh karena itu sangat penting ketika berbicara mengenai isu literasi untuk melihat dalam konteks dunia global dan digital yang dinamis tanpa batas.

Berdasarkan uraian di atas maka realitas kehidupan masyarakat saat ini tidak lepas dari gadget disisi lain literasi membaca dan menulis masih rendah maka diperlukan langkah strategis untuk mendukung gerakan literasi nasional yaitu bagaimana menyiapkan media literasi yang mampu membangkitkan semangat literasi masyarakat salah satunya adalah E-Modul. E-Modul merupakan media pengajaran digital dan non cetak yang disusun 
secara sistematis dan digunakan untuk keperluan belajar mandiri, sehingga dapat menuntut siswa untuk belajar memecahkan masalah dengan caranya sendiri. E-modul merupakan inovasi terbaru dari modul cetak yang bisa diakses menggunakan smartphone. Adapun permasalahan yang di angkat dalam tulisan ini adalah Pemanfaatan e-modul berbasis smartphone sebagai media literasi masyarakat.

\section{E-Modul}

E-modul merupakan sebuah bentuk penyajian bahan belajar mandiri yang disusun secara sistematis ke dalam unit pembelajaran tertentu, yang disajikan dalam format elektronik, dimana setiap kegiatan pembelajaran didalamnya dihubungkan dengan tautan (link) sebagai navigasi yang membuat peserta didik menjadi lebih interaktif dengan program, dilengkapi dengan penyajian video tutorial, animasi dan audio untuk memperkaya pengalaman belajar (DPSMA, 2017). E-modul mempunyai karakterisitik sebagai berikut: (1) self instructional, siswa mampu membelajarkan diri sendiri tidak bergantung pada orang lain, (2) self contained, seluruh materi pembelajaran dari satu unit kompetensi yang dipelajari terdapat di dalam satu modul, (3) stand alone, modul yang dikembangkan tidak bergantung pada media atau tidak harus digunakan bersama-sama dengan media lain, (4) adaptif, modul hendaknya memiliki daya adaptif yang tinggi terhadap perkembangan ilmu pengetahuan dan teknologi, (5) user friendly modul hendaknya juga memenuhi kaidah akrab bersahabat/akrab dengan pemakainya, (6) konsisten dalam penggunaan font, spasi, dan tata letak, (7) disampaikan dengan menggunakan suatu media elektronik berbasis komputer atau smartphone, (8) memanfaatkan berbagai fungsi media elektronik sehingga disebut sebagai multimedia, (9) memanfaatkan berbagai fitur yang ada pada aplikasi software, (10) perlu didesain secara cermat.

Keunggulan e-modul antara lain: (1) meningkatkan motivasi siswa, karena setiap kali mengerjakan tugas pelajaran yang dibatasi dengan jelas dan sesuai dengan kemampuan (2) setelah dilakukan evaluasi, guru dan siswa mengetahui benar pada modul yang mana siswa telah berhasil dan pada bagian modul yang mana mereka belum berhasil (3) bahan pelajaran terbagi merata dalam satu semester (4) pendidikan lebih berdaya guna karena bahan pelajaran di susun menurut jenjang akademik, (5) penyajian yang bersifat statis pada modul cetak dapat diubah menjadi lebih interaktif dan dinamis, (6) unsur verbalisme yang terlalu tinggi pada modul cetak dapat dikurangi dengan menyajikan unsur visual dengan penggunaan video tutorial. Adapun kelemahan e-modul adalah: (1) biaya pengembangan bahan tinggi dan waktu yang dibutuhkan lama, (2) menentukan disiplin belajar yang tinggi yang mungkin kurang dimiliki oleh siswa pada umumnya dan siswa yang belum matang pada khususnya, (3) membutuhkan ketekunan yang tinggi dari fasilitator untuk terus menerus memantau proses belajar siswa, memberi motivasi dan konsultasi secara individu setiap waktu siswa membutuhkan (DPSMA, 2017)

Prinsip pengembangan e-modul adalah: (1) diasumsikan menimbulkan minat bagi siswa, (2) ditulis dan dirancang untuk digunakan siswa, (3) menjelaskan tujuan pembelajaran, (4) disusun berdasarkan pola belajar yang fleksibel, (5) disusun berdasarkan kebutuhan siswa yang belajar dan pencapaian tujuan pembelajaran, (6) berfokus pada pemberian kesempatan bagi siswa untuk berlatih, (7) mengakomodasi kesulitan belajar, (8) memerlukan sistem navigasi yang cermat, (9) selalu memberi rangkuman, (10) gaya penulisan komunikatif, interaktif dan semi formal, (11) dikemas untuk digunakan dalam proses pembelajaran, (12) memerlukan strategi pembelajaran, (13) mempunyai mekanisme untuk mengumpulkan umpan balik, (14) menunjang self asessment, (15) menjelaskan cara mempelajari buku ajar, (16) perlu adanya petunjuk sebelum sampai sesudah menggunakan e-modul.

\section{Prosedur penyusunan E-modul}

Prosedur penyusunan e-Modul terdiri dari: (1) Tahap analisis kebutuhan e-modul, (2) Tahap desain e-Modul, (3) tahap validasi dan penyempurnaan. Untuk lebih jelasnya prosedur penyusunan e-Modul akan dijelaskan sebagai berikut: Tahap analisis 
kebutuhan e-modul, desain modul ditetapkan berdasarkan rencana pelaksanaan pembelajaran (RPP). RPP yang digunakan untuk desain e-modul adalah RPP yang dirancang agar siswa dapat belajar secara mandiri. Materi atau isi modul ditulis harus sesuai dengan RPP yang disusun. Isi modul mencakup subtansi yang dibutuhkan untuk menguasai suatu kompetensi.

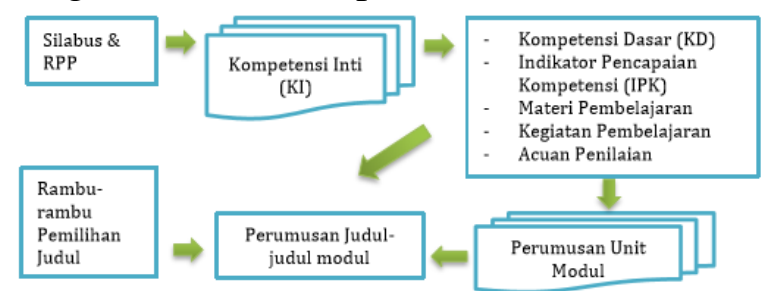

Gambar 1. Skema Analisis Kebutuhan EModul

(Sumber: DPSMA, 2017)

Tahap Desain e-modul, penulisan modul dilakukan sesuai dengan RPP yang berbasis aktivitas belajar mandiri, namun apabila RPP belum ada, maka dapat dilakukan dengan langkah sebagai berikut: (1) tetapkan bahan yang akan disusun, (2) tujuan akhir yang harus dicapai setelah mempelajari suatu modul, (3) tetapkan kemampuan spesifik yang menunjang tujuan akhir, (4) sistem evaluasi, (5) garis besar materi untuk mencapai tujuan yang ditetapkan.

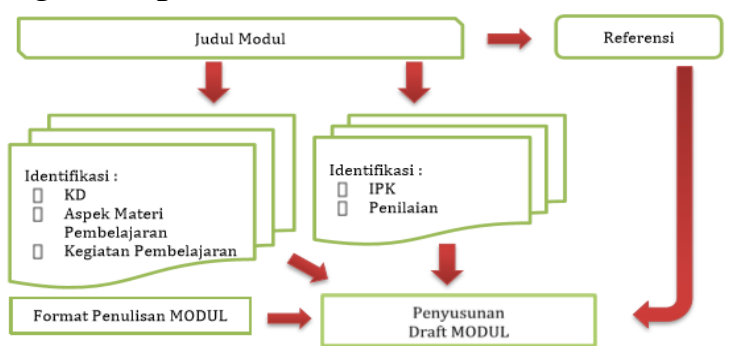

Gambar 2. Skema Desain e-Modul (Sumber: DPSMA, 2017)

Tahap validasi dan penyempurnaan eModul, setelah dianalisis dan didesain sebuah e-modul harus dilakukan validasi dan penyempurnaan dengan alur sebagai berikut:

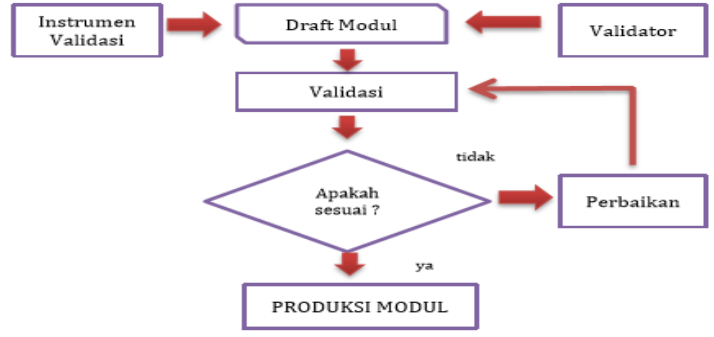

Gambar 3. Alur validasi dan penyempurnaan e-Modul.

(Sumber: DPSMA, 2017)

Tahap Penyusunan Naskah e-Modul

Penyusunan naskah e-modul terdiri dari berbagai langkah sebagai berikut: (1) penyusunan modul dalam microsoft word, (2) pemilihan aplikasi yang dipakai untuk membuat e-modul (aplikasi sigil), (3) instalasi aplikasi sigil, (4) migrasi modul dalam bentuk microsoft word ke aplikasi sigil, (5) verifikasi dan validasi, (6) membaca e-Pub dalam smartphone.

\section{Smartphone}

Smartphone adalah telepon genggam yang mempunyai kemampuan dengan penggunaan dan fungsi yang menyerupai komputer (Wikipedia). Smartphone dapat juga dapat diartikan sebagai sebuah telepon genggam yang bekerja dengan menggunakan perangkat Smartphone bekerja menggunakan seluruh perangkat lunak sistem operasi (OS) yang menyediakan hubungan standar dan mendasar bagi pengembang aplikasi. Ada juga yang mendefenisikan smartphone sebagai sebuah telepon pintar yang memiliki fitur canggih seperti email, internet, pembaca e-book dan lainnya. Wiliams dan sawyer smartphone adalah telepon selular yang memakai beberapa layanan seperti layar, mikroprosesor, memori dan modem bawaan. Ridi ferdiana menjelaskan smartphone adalah perangkat telepon selulerr yang dilengkapi dengan berbagai fitur dengan begitu selain sebagai alat komunikasi smartphone juga digunakan untuk keperluan bisnis oleh pengusaha dan masyarakt umum. David wood menjelaskan arti smartphone adalah handphone cerdas yang memiliki kelebihan di banding alat telekomunikasi lainnya. Berdasarkan pengertian di atas bahwa smartphone adalah komputer kecil yang memiliki kemampuan seperti telephone. 
Ketersedian perangkat pendukung seperti smartphone yang beredar di Indonesia dan jumlah penggunanya sangat besar dapat di manfaatkan untuk mengenalkan e-modul sebagai media literasi untuk perangkat tersebut, oleh karena itu untuk membaca sebuah e-modul diperlukan format yang dapat menyesuaikan dengan tampilan layar. Penggunaan format yang mendapat dukungan secara luas baik untuk pembuataanya atau aplikasi alat bacanya salah satu pilihan aplikasi baca adalah Electronic publication (ePub). ePub merupakan salah satu format buku digital yang disepakati oleh International Digital Publishing Forum (IDPF) pada oktober 2011. ePub mengantikan peran open e-book sebagai format buku terbuka. Format Epub mendukung penyesuaian tampilan teks sesuai dengan ukuran layar kecil perangkat tertentu. pada format Epub 3.0 sudah dimungkinkan menyertakan fitur audio maupun video serta animasi ke dalam buku digital. Format Epub merupakan salah satu format buku digital yang paling populer saat ini dengan berbagai kelebihan yang ditawarkan telah menjadikan ePub sebagai salah satu format buku digital yang paling banyak digunakan.

\section{Literasi}

Istilah literasi dalam bahasa latin disebut sebagai literatus yang artinya adalah orang yang belajar. Nasional Institute for literacy menjelaskan bahwa literasi adalah kemampuan seseorang untuk membaca, menulis, berbicara, menghitung dan memecahkan masalah pada tingkat keahlian yang diperlukan dalam pekerjaan, keluarga dan masyarakat. Education Development Center (EDC) juga turut mengeluarkan pengertian dari literasi yaitu kemampuan individu untuk menggunakan potensi serta skill yang dimilikinya. Menurut UNESCO (2006), literasi merupakan keterampilan kognitif dalam membaca dan menulis yang tidak hanya terikat pada konteks sumber dan cara pemerolehan keterampilan tersebut. Hal ini disebabkan pemahaman literasi seseorang terpengaruh oleh kondisi akademis, lingkungan, unsur-unsur budaya, dan pengalaman orang tersebut. Dengan demikian secara umum literasi berarti kemampuan seseorang untuk mengelola dan memahami informasi ketika membaca maupun menulis. Ada 6 jenis literasi yang dijabarkan dalam buku desain induk gerakan literasi sekolah (Wiedarti \& Kisyani-Laksono, 2016) yaitu: (1) literasi dini, (2) Literasi dasar, (3) literasi perpustakaan, (4) literasi media, (5) literasi teknologi dan (6) literasi visual. Berdasarkan jenis-jenis literasi tersebut maka tulisan ini, lebih fokus membahas bagaimana menyiapkan media literasi untuk meningkatkan literasi dasar masyarakat khususnya literasi bahasa.

Pemanfaatan E-modul sebagai media literasi masyarakat menjadi menarik untuk diterapkan dalam kehidupan masyarakat kita, karena e-modul disajikan dalam format elektronik, dengan program interaktif yang dilengkapi dengan penyajian video tutorial, animasi dan audio. Penyusunan e-Modul berbasis smartphone sebagai media literasi masyarakat tidak berbeda jauh dengan emodul yang disusun sebagai media pembelajaran di sekolah. E-modul sebagai media pembelajaran di sekolah desain pembuatan e-modulnya disusun berdasarkan Rencana Pelaksanaan Pembelajaran (RPP), agar siswa dapat belajar secara mandiri dan lebih interaktif karena siswa dapat melakukan evaluasi diri terhadap suatu kompetensi, sekaligus dapat melakukan tindak lanjut setelah mengetahui hasil evaluasi yang dilakukan secara mandiri, sedang e-modul berbasis smartphone sebagai media literasi masyarakat disusun berdasarkan kebutuhan riil masyarakat, judul atau tema yang di angkat adalah hal-hal yang menarik, yang lagi update dalam kehidupan masyarakat agar masyarakat di sajikan informasi yang menarik dan jelas sumbernya dan tidak interaktif. Penyusunan naskah e-modul berbasis smartphone terdiri dari: (1) penyusunan naskah dalam microsoft word, (2) pemilihan aplikasi yang dipakai untuk membuat e-modul (aplikasi sigil), (3) instalasi aplikasi sigil, (4) migrasi naskah dalam bentuk microsoft word ke aplikasi sigil, (5) verifikasi dan validasi, (6) membaca e-Pub dalam smartphone.

E-modul sebagai media literasi masyarakat diharapkan mampu mengalihkan perhatian masyarakat yang awalnya 
memanfaatkan smartphone hanya untuk sosial media tetapi dengan materi yang dikemas menarik dalam bentuk buku elektronik yang dilengkapi dengan video dan audio diharapkan dapat meningkatkan literasi masyarakat, hal ini sejalan dengan hasil penelitian yang dilakukan oleh Jaka Warsihna (2016) menjelaskan bahwa perangkat Teknologi informasi dan komunikasi (TIK) dapat digunakan untuk meningkatkan literasi membaca dan menulis yaitu televisi, internet, e-book dan audio book. Kemudian didukung oleh penelitian yang dilakukan Rizan \& Ika (2018) menjelaskan bahwa e-modul berbasis literasi sains sangat layak untuk digunakan dalam proses pembelajaran di sekolah. Dengan e-modul memudahkan suatu komunitas untuk mendapatkan bacaan yang menarik dan murah dan dapat diakses di mana saja, kapan saja serta penyimpanannya mudah dan ringan dapat dibawah kemana saja, sedangkan bagi penulis kehadiran teknologi ini dapat dimanfaatkan untuk mendistribusikan kepada pembaca tanpa harus mencari penerbit dan seleksi yang ketat, sehingga dapat mengeskpresikan potensinya kapan saja dan tentang apa saja sesuai dengan kebutuhan komunitasnya. Kesimpulan berdasarkan uraian di atas salah satu usaha untuk meningkatkan literasi masyarakat khusus literasi bahasa, adalah menyiapkan emodul sebagai media literasi masyarakat.

\section{DAFTAR PUSTAKA}

Atmaji, Rizan Dwi \& Maryani Ika. 2018. Pengembangan E-modul Berbasis Literasi Sains Materi Organ Gerak Hewan dan Manusia Kelas V SD. Fundadikdas. Vol 1 No. 1.

DPSMA, 2017. Panduan Praktis Penyusunan E-modul. Dikdasmen: Jakarta

Kemendikbud. 2017. Panduan Gerakan Literasi Nasional. Tim GLN Kemendikbud: Jakarta

Kemendikbud. 2017. Materi Pendukung Literasi Digital. Tim GLN Kemendikbud: Jakarta.

Kominfo. 2017. Survei Unesco Minat Baca Orang Indonesia Terpuruk. (Online)

(https://diskominfo.belitungkab.go.i d/2017/04/26/survey-unesco-minatbaca-orang-indonesia-terpuruk/.,_di akses 31 Desember 2019).

Warsihna, Jaka. 2016. Meningkatkan Literasi Membaca dan Menulis dengan Teknologi Informasi dan Komunikasi. Kwangsan, (Online), Vol 4. No. 2, (https://media.neliti.com/media/, diakses 25 Desember 2019).

https://www.researchgate.net/profile/Abdul_S aleh3/publication/242733505_Pera nan_Teknologi_Informasi_dalam Meningkatkan_Kegemaran_Memba ca_dan_Menulis_Masyarakat/links/ 57313c0008aed286ca0dcaaa.pdf, di akses 31 desember 2019).

https://www.kominfo.go.id/content/detail/108 62/teknologi-masyarakat-indonesiamalas-baca-tapi-cerewet-dimedsos/0/sorotan_media, di akses 31 Desember 2019). 